Lucy Neave

\title{
Being read: How writers of fiction manuscripts experience and respond to criticism
}

\begin{abstract}
This paper brings into dialogue contemporary discourse in creative writing studies about approaches to reading draft fiction with a subjective account of the experience of being read. Through drawing on two key essays on reading strategies in the discipline of creative writing, statements by published authors and my own process, this paper looks at how writers respond to feedback on their writing. Reading of draft creative work occurs in overlapping contexts in universities, by informal networks of writers and by editors - and social structures such as reading and writing groups support a writer in his or her response to criticism. The changes made to manuscripts as a result of feedback can be significant; this paper looks at the contexts in which such changes are executed. Ultimately, this paper argues that 'communities of practice' composed of writers who attended a university creative writing program together and who continued to read each other's work after graduation utilised and developed strategies initiated in such programs. Such communities have benefits for their members in terms of social support and publication.
\end{abstract}

Keywords: reading, theory, community of practice

I began writing a novel in 2003 from the perspective of two characters - a husband and wife - which initially took the form of fragments. The novel was originally set in 1999-2000, but soon after I began writing I made it historical, setting it in the years between 1938 and 1953. While at the outset the manuscript was purportedly written by the principal characters and told retrospectively, I made it linear and dispensed with the husband's perspective. The events in the novel were also refined over this period. In early drafts not a great deal happened; when the book, Who We Were (2013), was published it contained a series of dramatic events. A number of revisions early in the process resulted from my own reading of the manuscript, which revealed sentences, paragraphs and plot points that called for refinement or development. I was also reliant on comments from my agent, editors and readings by friends who were working on novels. As a result of these comments, I saw the book in a new way, and it was my peers' sense of the manuscript in particular, which they communicated to me in emails, that caused me to return to the draft in an attempt to make it a more credible and affecting piece of fiction.

The following paper gives an account of one short phase in the novel's development in the context of current discussions in creative writing scholarship about the reading of student manuscripts. It aims to bring into dialogue the theoretical discussion about reading with the lived experience of 
being read, and to draw some inferences about receiving feedback from discussions in creative writing studies and from experience. While this paper uses interviews and a small amount of archival material by published writers, it also relies on my own subjective account, which I am not claiming is an accurate transcription of my experience, since it has been retrospectively reconstructed. There is apparently little scholarship on the experience of being read and the impact of criticism on writers' final drafts; my account is an attempt to contribute to this sphere of knowledge.

In creative writing workshops in universities, the writer receives oral and sometimes written comments from several workshop members and/or the lecturer/tutor. Revision of draft work can be encouraged or even mandated by lecturers. As Andrew Cowan mentions when discussing Dianne Donnelly's Does the Writing Workshop Still Work? (2010), the workshop operates through a range of formats from the 'generative workshop' in which students respond to exercises or prompts during the workshop to the 'peer review' workshop, in which students read and offer comments on each other's work either in small groups or under the guidance of an instructor as a whole workshop (Cowan 2012). Related to the peer review workshop model are the informal networks created by writers who construct their own 'communities of practice' (Nelson \& Cole 2012) [1], which may develop alongside workshops in universities. Readings of draft work in informal networks and by publishers tend to be formalist. By 'formalist', I mean that the critical focus is on the work's intrinsic qualities, rather than on its context, how it was constructed or how it might be subject to social or political critique (Murfin \& Ray 1998). This paper argues that reading conducted on draft work occurs in overlapping fields: in universities, among informal networks of writers and by agents and editors, that these fields are not separate, and that readings conducted in each field have a bearing on a piece of draft fiction. In this paper, I advocate a heightened awareness of the spheres in which reading happens: that it would be pedagogically advantageous to develop a more open conception of reading and writing networks which operate around universities.

\section{Theoretical approaches to reading draft fiction}

Besides echoing critiques made by Dawson (2005) and Wandor (2008) of 'reading as a writer', these being that formalist critique ignores 'historical, socio-political, ideological and affective dimensions of literature' (Jarvis 2011), Jarvis argues that formalist reading strategies - which he equates with 'reading as a writer' - set up a binary opposition between reading and writing. For Jarvis, this is problematic because in his opinion reading and writing should not be considered distinct activities. Using Barthes' essay 'On Reading', Jarvis stresses the importance of 'writerly reading'. Writerly reading is the mode of 'writing' which involves reading not in a desire to emulate, 'to write like the author we enjoy reading,' but instead to incite 'the desire the author had for the reader when he was writing ... the love-me which is in all writing' (Barthes 1989: 40-41, cited in Jarvis 2011). For Barthes, 'reading is a veritable production ... literally for the work'; that is, reading engenders writing, not writing that is imitative, but a desire to write in a society of 'consumption ... of reading, seeing and hearing'. It is Barthes' contention that reading cannot be liberated 'unless writing is liberated' (Barthes 1976: 41), that is, writing takes place among those who are 'scattered, clandestine, crushed by a thousand even internal - constraints' (Barthes 1976: 41). Jarvis argues that the situation in the discipline of creative writing is reversed, and that 'reading as a writer turns Creative Writing in the academy into a society of writing in which reading is trammelled, its praxis limited to certain prescribed modes' (Jarvis 
2011). Jarvis, then, argues that reading needs liberation rather than writing. By this, he means that reading ought not be an instrumental activity, in which reading is directed in order for students to emulate successful texts, but for students to experience the 'authorial desire' for the reader in a broad and omnivorous conceptualisation of reading. Jarvis's issue with reading for a work's formal qualities is that it is normalising and may stifle the writing of experimental fiction which 'adopts a transgressive, subversive stance towards literary conventions and, therefore, destabilises orthodox ways of perceiving the world' (Jarvis 2011). Formalist critique, according to Jarvis, also privileges the unity of a text, imposing coherence where none may be necessary and/or desirable. For Jarvis, to read after Barthes and de Certeau (whose desire machines serve as the primary model for reading in Jarvis's paper [2]) is to create an almost utopian, progressive discipline, an ideal place in which radical and transgressive texts are produced, texts which are 'strange', meaning texts which are separate and alien, remaining implacably other. In order to write these kinds of texts, reading too must be 'liberated'. For Jarvis, it is therefore important for student texts to be read not on the basis of how they might be revised, for fear of directing a writer towards conformity rather than innovation.

One aspect of the debate about reading that Jarvis does not acknowledge relates to the tension in creative writing studies about the nature of the work produced. On the one hand, many exponents of the discipline see it as offering a way of theorising radical approaches, and as being able to support and provide a readership for work that is experimental. On the other, students enrol in creative writing courses in part to improve their writing, and/or to determine if they have a future as a writer. In a small Australian study (38 respondents) of the motivations of students who enrolled in undergraduate creative writing courses, Scott Brook found that for the majority the main reason they enrolled was to improve their 'personal skills'; meaning 'you want to develop your creative potential, learn to express yourself with confidence, and/or discuss writing from a more personal perspective' (Brook 2012). The second and thirdranked reasons for students to enrol in a course were to improve their writing skills and because they wished to have a career in writing and publishing. Acquiring knowledge about literary writing was ranked last (Brook 2012). This albeit limited research suggests that the way some students view the discipline differs from the value attributed by researchers to the development of research and knowledge in the field.

Cowan takes account of this dimension of the discipline when he argues that there is a bifurcation between "pedagogies oriented towards "skills" and those oriented towards "knowledge"" (Cowan 2012). Cowan cites Harper and Kroll (2008) who 'identify two understandings of what may count as a successful outcome in Creative Writing ... "publication or performance"” and research or creative experimentation which is 'liberated from commercial considerations' (Cowan 2012). That is, Cowan highlights the tension between valuing a radical, experimental form of writing - a kind of writing untainted by commercial imperatives - and that which has the potential to earn its author a living. This bifurcation raises questions about the purpose of the discipline: whether the role of creative writing, as taught in universities, is to 'produce' writers and/or improve the skills of students for the job market and careers in publishing, or whether it has an intrinsic scholarly value by contributing to a body of knowledge. The kinds of readings in creative writing studies, for the most part, are on the side of generating research and knowledge, rather than on the side of viewing creative writing as a vocational program for aspiring writers. In particular Jarvis (2011) and Wandor (2008) argue against the kind of pedagogy (and reading) that is formalist, or 'reading as a writer', and propose alternatives, such as 'writerly reading' (Jarvis 2011). Those who take a middle 
way, such as Cowan, do not see creative writing courses as inevitably producing great talents, but acknowledge the desire on the part of students to develop their practice and the potential for the discipline to contribute to the writing of works of integrity.

Cowan's paper is a more overt intervention into workshop pedagogy than Jarvis's, and makes distinctions between the peer-review workshop and the generative workshop to counter criticism of the workshop by Wandor in particular. For Cowan, the 'peer-review workshop' is an important mode, although probably only useful for graduate and high-performing undergraduate students. The peer-review workshop, in which works are discussed in order to help the writer to develop and revise them, 'enables a flexibility and inventiveness of approach to its discussion that is analogous to the conditions of its production' (Cowan 2012). That is, the reading of the work is also a creative act, which enables 'inventiveness' which can then be fed back into the work itself. Cowan, although focusing on the work, is arguing that discussion about writing in the workshop entails 'an acknowledgment of both its authoredness and its separateness from its author ... the workshop attends to the words on the page and what they, not the author, may reveal of their meaning and potential for future reworking' (Cowan 2012). The reading is a formalist one: it focuses on the intrinsic properties of the text, but it goes further than this, encouraging change and revision; Cowan views the reading itself as 'creative'. For Cowan the writing process is not a wholly conscious one. Therefore, reading admits aspects of the work that the writer is not conscious of, and the reading of these aspects can assist the writer in developing the work. The 'ideal' collective reading, in a higher education setting, will enable the writer to gain a better sense of his or her intentions for the work and an idea of the responses of readers, and may provide useful suggestions to the author to help him/her develop the work so that it realises its potential (Cowan 2012).

Both Cowan and Jarvis discuss the experience of reading from the perspective of being inside institutions, although the distinction between readings conducted inside and outside universities is not as clear cut as it may appear. Students studying creative writing share work outside the workshop, may read earlier or later drafts informally and are likely to talk about work discussed in class outside the workshop. Neither Cowan's nor Jarvis's essay is directly about the experience of being read, which is the subject of this paper, but they set up useful parameters for the discussion of this experience. These parameters pertain to the usefulness of formalist readings, the potential of other reading strategies for the development of the draft text and the extent to which revision is advocated.

How reading of draft work is conducted, who it is conducted by and what sort of feedback is given are therefore important questions for a discipline which is based on the production and reading of creative work. This paper argues that for the purposes of publication, a reading strategy for draft work which focuses on the text, is 'creative', admits the possibility of 'strangeness', emphasises the most interesting aspects of a text and at the same time encourages their refinement, is most useful. Such a reading strategy is nowhere near as radical as Jarvis's - reading and writing remain separate activities; reading is still potentially trammelled, which is problematic - although the kind of omnivorous reading Jarvis advocates must still be championed.

\section{Published writers and communities of practice}


Published writers outside the academy appear to elicit feedback from other writers, family members and friends and are edited to a greater or lesser extent. Research on the extent to which published writers are reliant on feedback, and research on the kind of reading they perform on their own and/or other's work is scant, though. Nelson and Cole view the kind of feedback and support writers require from each other as existing along a continuum, where some writers thrive on and provide 'intimate and painful advice', while others prefer to work in isolation (Nelson \& Cole 2012: 397). One of the writers interviewed by Nelson and Cole was immersed in a 'community of practice' and drew inspiration and feedback from other writers in this community, while the other, a male poet who socialised with other poets, said 'I don't share drafts ... I send off things to people and occasionally people will send back a comment or so' (writer qtd in Cole \& Nelson 2010). The second author's quote seems contradictory: on the one hand, he says that he doesn't share drafts, but on the other he admits to sending poems to people, and that he sometimes receives 'a comment or so' (Nelson \& Cole 2012: 399). Both writers appear to obtain feedback on their work, but the value they attribute to that feedback is different.

A 'community of practice', as defined by Nelson and Cole, is a group of practitioners who work in a loose and changing affiliation and are involved in 'experiential and collective learning' (Nelson \& Cole 2012: 400). That is, 'learning' is a facet of a community of practice, although such communities are not necessarily tied to educational institutions. Experience in such institutions is likely to be influential since networks and friendship groups emerge in the course of study. A community of practice is also a 'purposeful group of practitioners who regularly engage in information and skill sharing and collectively reflect on ways they can be more effective and efficient in their daily work' (Nelson \& Cole 2012: 400). From this quotation, it is evident that the notion of the community of practice comes from studies of scientific communities, and is also applied to collective learning within corporations (Cole \& Nelson 2010). I use the term 'community of practice', like Nelson and Cole, as a way of naming a group of writers who discuss each other's work and sustain each other in an informal and changing network. Other ways of thinking about relationships between writers are that of the mentor-emerging writer relationship, although these kinds of relationships may also intersect with literary networks.

One way of identifying the importance of feedback on draft writing by authors is through the paratext of the acknowledgments. For example, in the acknowledgements for On Beauty (2005), which appear before the novel, Zadie Smith writes: 'My gratitude to my first readers, Nick Laird, Jessica Frazier, Tamara Barnett-Herrin...' and lists a further five names (Smith 2005: 1). The precise role these readers played in the writing of the novel cannot be ascertained by reading the acknowledgments, but these readers are named as 'the first', meaning that they read an earlier draft than Smith's editors.

In the acknowledgements for True History of the Kelly Gang, Peter Carey mentions readers of the manuscript, including Sharon Olds and David Williamson, 'who read late drafts of the manuscript and contributed useful and constructive criticism' (Carey 2000: 401). Carey's acknowledgments come after the novel. Included in the extensive manuscript and correspondence holdings of material related to the writing of True History of the Kelly Gang in the State Library of Victoria is an email from David Williamson, dated 3 November 1999. Among a good deal of praise for the novel, Williamson writes: 'I did feel cheated over the cursory treatment of the Jerilderie incident. It is sort of well-known, but not that well known and I thought it cried out for a narrative treatment similar to the way you handle Euroa' (Williamson 1999 email to Peter Carey) (Carey 1998-1999). Written in blue pen in Carey's hand 
on this email, are the words 'I took his advice'. This act on the part of Carey appears to anticipate the reading of the archive: it looks to have been constructed with a reader or scholar in mind. In a subsequent email (dated 4 November 1999), Williamson writes: 'Peter I think that was exactly what was needed. The nonchalance with which they commandeered the town is breathtaking and makes great reading'. In one day, Carey rewrote the section of the novel about the Jerilderie incident in response to Williamson's feedback, as a newspaper article in the 'Jerilderie Gazette' (Carey 2000: 354-358) which documents how the Kelly Gang took over the town. It is interesting that Williamson's comments largely pertain to one incident, and the criticism he offered Carey was slight: a reference to his 'feel[ing] cheated' and a suggestion that Carey give it 'narrative treatment' meaning that he write the narrative of what happened in Jerilderie fully. This comment is not purely formalist, but references historical events and measures Carey's historical novel against what Williamson knows of Kelly's history.

Interviews frequently focus on a writer's solitary process, rather than asking about the extent to which writers seek and receive feedback. However, two brief examples of writers who discuss the extent to which they share draft work are given below. Sue Woolfe, when talking about the genesis of her novel, Painted Woman, says:

A friend of mine, Susan Hampton, had read ['Wigs'] and said: Why is this woman like this - she's so self-negating! It was one of those comments that's pivotal, and straight to the heart. So I thought, OK, what I'll do is I'll write the early life of my 'Wigs' heroine... (Woolfe 1993: 256)

Woolfe ended up writing Painted Woman in part as a consequence of Hampton's intervention, starting with a younger and altered version of the woman in 'Wigs'. The resulting novel traces the growth of the narrator of the novel who was originally in 'Wigs'. Hampton's intervention - from the perspective of Woolfe - was vital, in that it enabled her to imagine a history for her protagonist and made the character a more nuanced and comprehensible subject. As with Williamson's comment, Hampton's appears quite brief. It is a question, rather than a statement about the text, which is asking Woolfe why a character is 'like this'. Of course, Woolfe may be reporting only a line from a much longer conversation, but she says that the comment was 'pivotal, and straight to the heart' (Woolfe 1993: 256) suggesting that even though the comment was brief it had an immense impact. This comment could be construed as formalist, but it would also be possible for a writer to take a comment like this personally, the subtext being, 'Why would you write a woman who is "so self-negating"?' (Woolfe 1993: 256).

The comments Carey and Woolfe received do not appear detailed, as comments from an editor might be, but they nonetheless affected the published novels. It is revealing that a writer of Carey's stature would approach fellow writers for comments, and that he might turn to them before submitting a novel for editing. In contrast, in an interview published in New Writing, Kate Grenville says that she doesn't 'show anything to anyone until I've pretty much come to the end of the road with it ... I show my family first, then my agent, then the publisher' (Grenville 2006: 16). Woolfe and Grenville, according to their interview responses, appear to occupy the two poles Nelson and Cole (2012) mention. Woolfe, at least in the writing of her first novel, used feedback from her friend when the manuscript was at an early stage of development, while Grenville does not elicit feedback until she feels the novel is finished. This does not mean that Grenville had no feedback on The Secret River; alterations after receiving editorial comments may have been significant. 


\section{The role of feedback in the writing of my own novel}

The first reading of my novel was carried out by an American agent, who acquired the work early in the writing process. His reading focused on minor grammatical issues and the work's uniformity of tone. He was hesitant to suggest large or structural changes. Up until that time, only a preliminary draft had been read while I was in an American graduate program. I made the changes the agent suggested and he sent the manuscript out to a few publishers. I could not have articulated the novel's flaws at that time, but feared that the manuscript would not find a publisher. He received some comments from editors. The book was 'too claustrophobic', the voices 'not distinct enough' and the sense of the time and place not sufficiently present in the novel. One editor wrote that the novel needed to be 'Graham Greene-d up 400 degrees'. These comments were unlike any that I had previously received because they were anonymous and from editors, rather than from readers in a university. They were not at all detailed, and were formalist only in the sense that they focused on the text. They could best be characterised as highly critical, although they included some words of praise for the writing and the characters. My readings of the novel were then inflected by the comments: I saw the novel in a new way, one which enumerated some of the novel's flaws, although the comments were so brief that I applied and extended them to other facets of the manuscript. Rather than having a vague sense of the book's 'wrongness', the critical comments on the part of editors gave me particularities about its failings. On the one hand, this was deeply disappointing: I was frustrated by my previous inability to see the manuscript's flaws and amend them. After receiving these comments, I was forced to seek creative solutions.

None of the editors was interested in making the book more 'strange', in the way that Jarvis advocates alterity. Instead, they wanted a book that would be relatively commercially successful. In order to make the book less claustrophobic and to give a fuller sense of the atmosphere of the time, I decided to introduce two other characters who belonged to the time and place of the novel - mid-twentieth century New York - and could serve as representatives from that time. As a consequence of adding these two characters, who at first felt as though they had been added for artificial reasons, my ideas about the novel's themes changed. It became clear to me that the novel was also necessarily about the impact of the political atmosphere on the characters. The text began to explore the relationship between these two couples. The editors' readings, then, had an impact on the characters and themes in the novel. My solution to the problems raised by the editors made the book nuanced in its depiction of the atmosphere of the time. While the editors were most interested in a book they could sell to a reading public, their comments did not direct me to make a more obviously commercial book, but in fact a more thematically complex one. Formalist readings, therefore, may not necessarily result in more 'conformist' work. In the end, Who We Were was not an experimental piece of fiction, but it became more interesting thematically as a consequence of what was quite slender feedback from editors.

The editors' comments made me decide that I needed more readers before my agent could submit the novel again, though, and that the kind of readers I needed understood the marketplace to which I was addressing the novel. I chose several readers whom I had met in graduate school, where my writing had been discussed in peer review workshops. These were friends of mine. Six of us met and discussed my work and the work of another writer. The experience of the university workshop guided our comments, which were largely formalist in that they focused on the intrinsic qualities of the work: on 
the characterisation, setting and tone of the manuscripts. We began by discussing the more successful, interesting aspects of the work and moved on to discuss what was felt to be less successful. We made suggestions for how any issues we encountered might be dealt with. For example, the similarities between the voices of my two principal characters was commented on, and suggestions were made for how to alter them. One of the other writers in the group suggested I read Wallace Stegner's Crossing to Safety (1987) which was about the relationship between two couples, living in a similar period to my characters. This suggestion turned out to be pivotal in the development of the relationship between Suzy and Frank Seredy and Bill and Annabel Whitton, the two couples in my manuscript.

In contrast to the workshops at university, we were more casual and probably more careful not to cause offense when making comments and the tone of the discussion was light-hearted. Jen Webb writes that 'society ... is an aggregation of individuals and small collectives predicated on antagonism, competitive practices' (Webb 2008: 127, also quoted in Cowan 2012) and certainly groups of writers are notoriously competitive. Nonetheless, the sense of competitiveness - palpable in university creative writing workshops - was put aside; some of us had no other trusted readers for our work to turn to. As a result, the environment felt supportive: this was writing to be shared in our small forum only; the work was not for grading, and it was understood that it was draft material which would be developed significantly. No authority figure in the form of a workshop leader was present, and the discussion was less structured than workshops held at a university, although it bore some resemblance to Cowan's ideal peer review workshop in that it was 'creative' in terms of the suggestions made for manuscripts under discussion, and because it enabled the writer to see aspects of the work she or he had been blind to, as a result of hearing readers' responses. There was no imperative to work towards experimentation, as advocated by Jarvis. This suggests that knowledge-making and experimentation may be part of an institutional agenda, although it is likely that other communities of practice stress experimentation to a greater extent. Our discussions were not limited to the writing, though. We also talked about upcoming social events and our jobs: the 'community of practice' was a social structure as much as a forum for critique of works-in-progress.

Of the writers in this community, all offered useful comments on the next draft, which they received by email. Their comments, like the editors' comments, inflected my reading of the manuscript. The readings conducted continued to focus on the flaws in the text: the novel's structure and the portrayal of the characters, while at the same time admitting the possibility of change and development of the text. Not all readings were critical, though. One of my readers sent me descriptive comments only: she read the novel and listed each chapter, whose perspective the chapter was from, the date, the role in the narrative, the action. This enabled me to see how each chapter contributed to the whole story. After the introduction of two new characters, two of my readers suggested only minor changes. The most critical and useful reading was by E, who was also an editor for a literary journal: her role as an editor and as a friend therefore overlapped. Her emailed comments cut to what then appeared to be the main issue with the book, which was the depiction of the relationship between the two principal characters, Bill and Annabel Whitton:

The descriptions of nature, the more sensual aspects of the story, are some of my favourite prose. I would love to see that same texture and depth given to the emotional aspects of the story and to their view of their own work... If you were to show them when they're happy, show them beginning to fall apart, and don't worry about explaining it, but instead dramatizing it, 
I think you will have a dramatic leap forward. (emailed comments 19 August 2007)

E went on to provide more examples of where the relationship between Bill and Annabel could be dramatized. E also suggested about the beginning:

what if we start where we start, and instead of watching all 3 be on the train, not speaking much, afraid or shy of interacting, they all go off and DO something together? Something they are not supposed to do, perhaps, or anything unexpected that frees them up, shows us the relationships between all of them? That would do in a scene much of what the whole first section does. (emailed comments 19 August 2007) [3]

E's reading therefore outlined one of the deficiencies in the novel: that the characters' relationships needed to be dramatised. Her reading also allowed for the possibility of the development of that drama. Without E's reading, the book would have remained unpublishable, because it would have been impossible for me to imagine the novel's main flaw. The novel was too concerned with explaining the events and their impact on the husband and wife and did not sufficiently dramatise what happened so that the reader could 'experience' the narrative. E was basically reiterating writing workshop dogma - 'show don't tell' - although in a specific and detailed manner, which imagined the book beginning in a different way, such that the characters 'all go off and DO something together'.

It was because of E's feedback that I rewrote the first three chapters. Instead of the characters sitting on a train, they are involved in a car accident in a remote part of Victoria, Australia. This has the effect of bringing the Bill and Annabel together much earlier in the book, allowing me to focus not on their romance, but on their marriage and its dissolution. As well as sending me a page-long summary of her comments, E also emailed me track changes on the manuscript, which specified where scenes could be developed and descriptive details could be added. E's critique focused on heightening the realist nature of the text; in fact, E's reading encouraged me to make it a more overtly realist novel. E's aesthetic, and her knowledge of the arena in which I was attempting to find a publisher for the work, affected her reading and comments on the work. My response to her suggestions, which was to attempt to make the alterations she suggested, inevitably resulted in a more consumable piece of work, in a manner that might be criticised by Jarvis. Aspects of Bill and Annabel's characters remained 'strange' and/or 'alien', however. Bill is never a legible character and Annabel's obsession with him is probably at times alienating for the reader. I could not argue, then, that the formalist critique offered by E inevitably resulted in wholly 'commercial' novel, although it meant that I was able to find a publisher.

As well as reading our work, $\mathrm{E}$ facilitated the publication of stories by another writer and me, advancing our respective careers. Although E's comments were the most useful of all those I received, the social support from the larger community of practice enabled me to make the changes to the novel. To an extent this support was intangible: it left no material trace, but it was nonetheless crucial to the completion of the manuscript. Of course, I do not regard this network of writers or the individuals which made up the group as unique. Instead, I imagine that there are thousands of informal networks of writers, who read each other's work, help each other attain publication and publicise each other's books. 
While the kind of reading conducted on my work was closest to formalist critique, as in Cowan's paper it also admitted the possibility of development, allowing the writer to maintain a sense of optimism for the work. My own reading and rereading of the text was not dominated by this kind of critique. A large part of the time I spent reading the novel - especially in the early stages of its writing - I was thinking about the novel's interest in ethics, how I could authentically represent the distinctive subjectivities of the characters and how to write a novel set in the past. To an extent these concerns are intrinsic to the novel, but at many stages in the process, I also read for discourse and ideology: how the novel represented a young woman living in the 1940s and 1950s and whether my representation of her was ideologically problematic for me. That is, at the same time as I was writing the novel, I was rereading my work from different vantage points. In all, I was immersed in several modes of reading. This indicates that teaching a range of theoretical approaches to reading at university is of use to developing writers, an argument I make in 'Unrealised Possibilities: Graduate Creative Writing Programmes in the USA' (Neave 2006). One aspect of the experience of being read is that it provides the writer with another angle on the work. Even if a rewrite was not read by E, for example, I could imagine how she would apprehend the text.

The opening section of this paper mapped a recent debate about reading conducted in scholarly journals. The second section of the paper looked at interviews and archival material to assess the importance of feedback for published writers. The final section demonstrated how comments on my novelin-progress had a bearing on the development of the manuscript, in order to look at how theoretical approaches to reading are applied outside universities, and as a way of highlighting the effects of criticism by fellow writers on a draft novel manuscript. The paper also takes account of the social support provided by an informal 'community of practice'.

As a consequence of the subjective experience of being read, I have argued that a formalist critique which emphasises the text as a site of possibility is useful for reading draft fiction manuscripts, particularly if the writer is aiming for publication. It is important for those of us working in universities to be aware of writing and reading communities which operate alongside formal workshops. Roanna Gonsalves, writing about her 'evolution' as a writer, and drawing on Bourdieu's notion of the field of cultural production, stresses the 'utterly social' nature of entering the literary field (Gonsalves \& Chan 2008). To this end, courses in collaborative practice, such as the one documented by Jen Webb in 'Acting, Interacting and Acting Up' (2008) heighten students' awareness of the social aspects of artistic practice and give students valuable experience in working together. Speaking explicitly about the usefulness of writing communities in undergraduate and graduate courses makes students conscious of the social nature of the 'literary field' despite the Romantic counter-narrative of the solitary artist. In a later year creative writing course at Australian National University, literary networks and relationships such as 'Canberra's Seven Writers' (Australian Women's Register 2012) and the competitive friendship between Katherine Mansfield and Virginia Woolf are discussed, alongside reading these writers' stories. Students can often contribute to discussions about contemporary online communities, or communities that exist in the flesh and online, such as 'Scissors Paper Pen' (no date), a Canberra literary community which runs workshops, social events and a book club for young and emerging Canberra writers.

While frantically multi-tasking writers who work in universities (see Webb 2004) cannot be expected to create and maintain social networks for students who are about to graduate, it is important to recognise that communities of practice develop in creative writing programs, and that their emergence can be 
facilitated by social events in such programs. Individuals in universities can encourage the formation of such networks (as many already do) through supporting writers' groups, student-run literary journals, readings, informal social events and by stressing social aspects of the literary field. In the end, such networks have enormous benefits for emerging writers and, ultimately, for literary culture.

\section{Notes}

[1] A 'community of practice' is 'a still evolving, contested and malleable concept, which refers to a situated, experiential and collective learning by practitioners with a shared interest' (Nelson \& Cole 2012: 400). That is, such a community focuses on 'experiential' learning, and is subject to change. In this paper, I apply the term to a group of writers who share work and support each other. Nelson and Cole cite Lave and Wenger (1991) and Wenger (2001) when discussing the notion of a 'Community of Practice' and attribute the idea to these scholars. return to text

[2] The most radical and interesting aspect of Jarvis's paper is his advocacy of De Certeau's celibatory machines as a model for reading and writing which 'offer a means of modelling composition as a fluid performance' (Jarvis 2011). Celibatory machines are performative 'texts, discursive spaces' (Jarvis 2011). '[T]he Celibatory machine creates its energies by repressing the desire for a reader that is in all writing, forcing it to return transfigured.' According to Jarvis, the 'writerly reading' praxis informed by de Certeau's idea of the celibatory machine would result in a 'recognition that the power [the reader/writer] has to disrupt ... a text's meanings.' Such a model of reading 'would force readers to recognise their otherness with respect to the texts they read ... be wary of the sleight of hand by which readerly texts promote belonging, engagement' (Jarvis 2011). return to text

[3] Permission granted by the emails' author to include them in this paper. return to text

\section{Works Cited}

Australian Women's Register 2012 'Seven Writers' (Internet Resource) Trove, Canberra: National Library of Australia: http://trove.nla.gov.au/people/752067?c=people (accessed 30 January 2014) return to text

Barthes, R 1989 'On Reading', in The Rustle of Language, trans R Howard. University of California Press, Berkeley CA: $32-43$ return to text

Brook, S 2012 'Creative Writing, Cultural Capital and the Labour Market' Australian Humanities Review 53: http://www.australianhumanitiesreview.org/archive/Issue-November2012/brook.html (accessed 9 July 2013) return to text

Carey, P 1998-1999 'Secret History of the Kelly Gang' manuscripts, MS F Box 3989. State Library of Victoria, Melbourne return to text

Carey, P 2000 True History of the Kelly Gang, University of Queensland Press, St Lucia, Qld return to text

Cole, C \& A Nelson 2010 'Literary communities: writers' practices and networks', Strange Bedfellows: Refereed Conference Papers of the 15th Annual AAWP Conference, 2010: http://aawp.org.au/files/Cole\&Nelson.doc.pdf (accessed 20 March 2013) return to text

Cowan, A 2012 'A live event, a life event: the workshop that works', TEXT 16, 1 (April): http:///www.textjournal.com.au/april12/cowan.htm (accessed 28 February 2013) return to text

Donnelly, D 2010 Does the Writing Workshop Still Work? Multilingual Matters, Bristol: http://books.google.com.au/books/about/Does_the_Writing_Workshop_Still_Work.html? id $=6 p 7 H v u B 9 S g U C \&$ redir_esc $=y \backslash($ accessed 1 July 2013) return to text 
Grenville, K 2006 'Interview', New Writing: International Journal for the Practice and Theory of Creative Writing 3, 1: 12-16 return to text

Gonsalves, R \& J Chan 2008 'Creating Fiction: Bourdieu's Theory and Writing Practice', TEXT 12, 1 (April): http://www.textjournal.com.au/april08/gonsalves_chan.htm (accessed 31 January 2013) return to text

Harper, G 2010 'Creative Habitats and the Creative Domain', New Writing: International Journal for the Practice and Theory of Creative Writing 7, 1: 1-4: http://dx.doi.org/10.1080/14790721003638661 (accessed 4 July 2013)

Harper, G \& J Kroll 2008 'Creative Writing in the University', in G Harper \& J Kroll (eds) Creative Writing Studies: Practice, Research and Pedagogy, Multilingual Matters, Bristol: 117129 return to text

Jarvis, T 2011 "“Pleasure balks, bliss appears" or "The apparatus shines like a blade": Towards a theory of a progressive reading praxis in Creative Writing pedagogy', TEXT 15, 2 (October): http://www.textjournal.com.au/oct11/jarvis.htm (accessed 28 February 2013) return to text

Lave, J \& E Wenger 1991 Situated Learning: Legitimate peripheral participation, Cambridge University Press, Cambridge return to text

Murfin, R \& S Ray 1998 The Bedford Glossary of Critical and Literary Terms: http://bcs.bedfordstmartins.com/virtualit/poetry/critical_define/crit_form.html (accessed 20 January 2014) return to text

Neave, L 2006 'Unrealised Possibilities: Graduate Creative Writing Programmes in the USA', New Writing: International Journal for the Practice and Theory of Creative Writing 3, 1: 56-64 return to text

Nelson, A \& Cole, C 2012 'Productive Creative Writers' Relationships: A Communities-ofPractice Framework', New Writing: International Journal for the Practice and Theory of Creative Writing 9, 3: 396-407: http://dx.doi.org/10.1080/14790726.2012.693095 (accessed 19 February 2013) return to text

Prose, F 2006 Reading Like a Writer: A Guide for People who Love Books and for those who Want to Write Them, Harper Perennial, New York

Scissors Paper Pen (n.d.) website: http://scissorspaperpen.wordpress.com/page/2/ (accessed 30 January 2014) return to text

Smith, Z 2005 On Beauty, Hamish Hamilton, Camberwell Vic return to text

Stegner, W 2002 [1987] Crossing to Safety, Modern Library, New York return to text

Wandor, M 2008 The Author is not Dead, Merely Somewhere Else: Creative Writing After Theory, Palgrave Macmillan, London return to text

Webb J 2004 'Multiple and Contradictory Interpellations: or, How to Juggle Cats', TEXT 8, 1 (April): http://www.textjournal.com.au/april04/webb.htm (accessed 31 January 2014) return to text

Webb, J 2008 'Acting, Interacting and Acting Up: Teaching Collaborative Creative Practice', in G Harper \& J Kroll (eds) Creative Writing Studies: Practice, Research and Pedagogy, Multilingual Matters, Bristol: 117-129 return to text

Wenger, E 2001 'Communities of practice' in International Encyclopaedia of the Social and Behavioral Sciences, Pergamon/Elsevier Science, Amsterdam 2339-42 return to text

Woolfe, S 1993 'Interview', in K Grenville \& S Woolfe (eds) Making Stories: How Ten Australian Novels Were Written, Allen \& Unwin, Sydney return to text 
literary journals. She is a lecturer in creative writing at the Australian National University.

\section{TEXT}

Vol 18 No 1 April 2014

http://www.textjournal.com.au

General Editor: Nigel Krauth. Editors: Kevin Brophy \& Enza Gandolfo text@textjournal.com.au 